Telangiectases in Children, in Association with Wasting and Protracted Dlarrhea.-FeArssines (Brilish Journol of Dermolology, February, 1912) reports a series of 6 enses, all in eliklelen, in whieh telangiectases, erythema, ond purpura oecurred in eonnection with wasting and protraeted diarrhei. The erythema was present in all the eases and in 5 was assoeiated witl telangieetases. Purpura occurred in 2 along with the erytherna and telangicetuses. The erythema was found usually on the distal portions of the extremities, while the tëlongieetases were ou the thighs ond parts of the trunk exposed to pressure. Edema was present in all the cases. Fearnsides coneludes that these various rashes were the expression of vasenlar dilatation, and were the direet result of the wasting hrought obout lyy the prolonged dintrhen.

Some Papulosqnamous Syphilldes and Their Relation to Psoriasis and Parapsoriasts.-Ravogut (.Archio $f$. Dermolologic tond Syphilis, Band exi, Heft 1), under the above title, diseusses the not infrequent close resemblanec cxisting between some populosquanous syphilides and psoriasis, anel reports briefly some cases in illustration. He concludes that in some instances psorinsis follows sypliilis as a metamorphosis of the papulor process. In some eases it is a lybrid form to be referred to an ottenuated luetie taint; and al thougl not the direet result of syphilis, it ean, in many instances, be regarded as a parasypliilitie affection. (TVe cannot agree with some of Rarogli's condusions as to the relutionslip betwcen syphilis and psoriusis. There is no evidenee to prove that the two diseases are even remotely related etiologically, -M. B. H.)

The Treatment of Darler's Disease by the Röntgen Ray.-Rirren (Dermolologische Woch., Hand liv, No. 6) reports a case of Darier's discase sueeessfully treated by means of the Röntgen ray. In the beginning of the treatment small doses were employed ( 3 to $5 x$ ), but without result. Larger closes $(10 x)$ were then tried, and to these the affection reaeted very promptly, the lyyperkeratoses disappearing without lenving any scar. Gradually the greoter part of the body was exposed to the rays, the resul tof the treatment being especially brilliant on the face, which was greatly disfigured by lyjperkeratoses. The trentment lasted about eighteen months, and Ritter believes the good results permanent.

Eosinophile Cells and "Mastzellen" in Vesicular Eruptions of the Skin.-Pultz (Arch. f. Dermolologic n. Syphilis, Bond exi, Heft 1), who has studied a large number of cases of vorious vesienlar eruptions such as eczema, seobies, herpes, etc., has found u considerable number of cosinophile cells and "mastzellen" in the vesieles of these disenses. In most seabies vesieles and in those of eczemo cosinophiles and "mastzellen" were found together, the number of the former, however, greotly exceeding the lotter. In the lesions of herpes labialis and progenitalis there was a high-grade cosinophilia nnd a marked increase in the number of "mastzellen," but in those of 2 eases of herpes zoster neither variety of eell was found. In the lesions produced by vesicants there was likewise a high-grade cosinopliile and basoplile leukoeytosis. 


\title{
PATHOLOGY AND BACTERIOLOGY
}

\author{
GNUER TUE CHAROE OF \\ JOHN MICCRAE, M.D., M.R.C.P.,

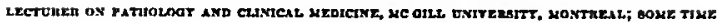

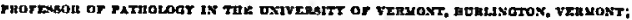

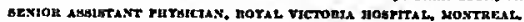

A Partly Successful Therapy for Cancer.-A preliminary communieation of greut interest was reeently made to the Medieal Society of Berlin upon this subject by Wasseraisxs, Kersser, and MI ICHAEL Wasseratans. It forms the subject of an article in the Deutsch. med. Woch.; December 21, 1911, and of a lender in the Brit. Med. Jour., January 6, 1912. These workers have been seeking a remedy that would exert a sclective action upon ncoplastic tissues leading to the destruetion of tbose tissues without effect upon the aormal body eells, and have met with a partial success in a compound of selenium, tellnrium, and cosin. No particulars of its eraet qualitative or quaatitative nature are to hand, but it may be said that the use of a large dose lias led to the dwindling and sosoetimes to the disappearanec of carcinomutous growths in laboratory aaimals. The growths experimented upon were in some enses transplantation, and in others spontaneous tumors; the eurious statement appears that if the required dose be injeeted into a healthy animal the ea tire skin of the animal beeomes pink (from the cosin), whereas, if a newerowth be present this does not oceur, but the tumor becomes an intense red, indicating a special affinity between the drug and the tumor cells. Tumors as large as a eherry lave disappeured under the treatment.

Inflammatorg and Arteriosclerote Ejdney Disease.-J. F. GASkELL (Jour. of Poth. ond Bacl., January, 1912), working at Freiburg, eontributes a paper containing the results of a painstaking examination of more than 60 kidneys. He coneludes that the glomerular and arterial changes give a means of differentiating certain forms of disease that is aecurately in kecping with the clinical history of the cases. Among inflammatory eases Gaskell segregates tlose in which the renal eliange aeeompanies uleerative enduenrditis, indicating them as embolie focal neplaritides; in these a charieteristie fibrinous exudate and leukocytie infiltration affecting some of the glomerular capillaries is found. In suelı cases, the renal nffection is a secondary one and the patient dies from the disease of the beart, and not from uremin, as is likely to lappen in the true glomerulotubular cases which are readily separated from the above by the microscopic cluanges. Permanent inflammatory elianges, apart from those seen in uleerative eadocarditis, are always due to true glomerulotubular nephritis, the effects of whieb are to be seen in different stages, the acute, known generally as aeute parenchymatous nepluritis, the subacute commonly ealled "large white kidney," and the selerotie, usually kaown as secondary contraeterl kidney, less well designated "small white kidney." In general, Gaskell 
supports the views of Löllein. The real ehauges due to general vaseular discase mark an eatirely distinct group, whicl includes those due to senile arterioselerosis and those in which a true primary contraeted hidney, due to arteriosclerosis of the small arteries, are seen. In the former, the senile form, the arteriosderosis is moinly seen in the aorta and other large vesscls, whence it spreads to the reaal arterioles, with marked atrophy and glomerular degeneration. Althougl a high degree of shrinkage may oceur, denth usually is due to intercurrent disease, and clinieally the group is an unimportant one. The latter form, where there is seen a genuine contraeted kidney, is seen in cases where a general, well-marked arterioselerosis of small arteries and arterioles leads to death from such a cause as cerehral hemorrhage.

The Cansative Agent of Searlet Fever.-Much activity has lately prevailed in attempts to convey to monkeys the virus of scarlet fever; prominent among workers have heen CANTAcuzENe, BERNHand, Vipond, Lavasteiner, Levadim and Prasex. Vipond holds for the eausative agent a large, readily-cul tivated haeillus. The three authors, last named, inoculated into the tonsils and uader the skin, scarlatinal produets and produced fairly satisfactorily the signs of the disease, hut their animals showed hlood eultures of streptococeus; the material does not produce symptoms unless inoculated into the tissues, and one is compelled to think that their experiments allow streptococei to eomplicate the results, although their own belicf is that there are effects that can be attributed only to another virus. More definite, perhaps, are Bernhardt's results with material scraped from the tongues of patients, injected partly under the skin, partly in the mouth-tissues of an ape, of which the inguinal nods were then emulsified and injeeted. This was repeated, and the third ape, treated with emulsion that had been filtered through a Berkefeld filter, slowed the exanthem, strawberry tongue, fever, subsequent desquamation, especially of the hands and feet, and occasional albuminuria. He thus thinks the disease to he due to a filterable virus, and appends a deseription of small hodies in the filtrate, which stain readily hy Giemsa's method, ond which he has found in the nodes and kidneys of individuals dend from the disease.

A Medium for Dlphtheria Bacinh.-Rankin (Journal of IIygienc, xi, 1911) has ohtained very aceurate resul ts in the recognition of diphtheria hacilli hy the use of $\mathrm{a}$ medium composed of slieep's blood scrum, 3 ports; houillon, 1 part; glucose, 0.5 per cent.; potassium sulphocyanide, 1 part; and 2 per eent. of a 5 per cent. solution of aentral red. The baeillus of diphtheria grows in rose-colored colonies, which are rendily distinguished from the colonies of those few other mierobes (ehiefly coeci), the growtl of which is not retarded by the medium.

Notice to Coatribators.-All communications intended for insertion io tbe Origioal Deportment of this Jovmsis, are received only trith the distinct understanding that they are contributed cadisately to this JovnNAI.

Contributioos from abrosd written in $\mathrm{n}$ forcign language, if on examination they are fouod desirable for this Jookss, will be translated ot its expense. A limited aumber of repriots in pornplilet fom, if desired, will be fumished to outhors, provided the request for them be urrilten on the manuscript.

All communieations should be oddresed to-

Dr. Geonoz Monus Piensol, 1927 Chestnut St., Plila., Pa., U. S. A. 